\title{
Adsorption Decolorization Technique of Textile/Leather - Dye Containing Effluents
}

Marian Deaconu $^{1 *}$, Raluca Senin ${ }^{1}$, Rusăndica Stoica ${ }^{1}$, Anca Athanasiu ${ }^{1}$, Marian Crudu ${ }^{2}$, Loti Oproiu ${ }^{1}$, Mircea Ruse ${ }^{1}$ and Catalin Filipescu ${ }^{1}$

${ }^{1}$ The National Institute for Research \& Development in Chemistry and Petrochemistry-ICECHIM Splaiul Independentei 202, sector 6, Bucharest, Romania

${ }^{2}$ Leather and Footwear Research Institute- ICPI, Ion Minulescu 93, sector 3, Bucharest, Romania

"Corresponding author: Marian Deaconu, The National Institute for Research \& Development in Chemistry and Petrochemistry-ICECHIM Splaiul Independentei 202, sector 6, Bucharest, Romania, Tel: +39 065007 4083; E-mail: deaconu319@yahoo.com

Received date: April 02, 2016; Accepted date: April 20, 2016; Published date: April 27, 2016

Copyright: (02016 Deaconu M, et al. This is an open-access article distributed under the terms of the Creative Commons Attribution License, which permits unrestricted use, distribution and reproduction in any medium, provided the original author and source are credited.

\begin{abstract}
The purpose of this study was to evaluate the potential of ion exchange resins to remove the color from industrial wastewaters. In textile-leather dyeing, paper, colour, printing, cosmetics, pharmaceutical and other industries the synthetic dyes are extensively used. Adsorption techniques are much used to remove certain classes of pollutants from waters, especially from industrial colored wastewaters. In recent years, functional polymers have been increasingly tested as a potentially alternative to traditional adsorbents due to their vast surface area, perfect mechanical rigidity, adjustable surface chemistry and feasible regeneration under mild conditions. The strongly basic anion exchanger resins were used as an adsorbent for the acid, direct and reactive dyes adsorption from the coloured wastewaters.
\end{abstract}

Keywords: Colored wastewater; Azo dyestuff; Adsorption; Ionic exchange (resin)

\section{Introduction}

Water-pollution control is now one of the major areas of scientific activity. Effluent discharge from leather, textile and dyestuff industries causing significant health concerns to environmental regulatory agencies. Color is the first contaminant to be recognized in wastewater and has to be removed before discharging into water bodies or on land. The economic removal of polluting dues is gaining great importance, particularly as new European Commission regulations on industrial effluent discharge are at present being enforced.

Synthetic azo dyes are used for a long time in textile-leather dyeing, paper, printing, color, photography, pharmaceutical, cosmetics and other industries. The textile and leather industry is one of the most complex and complicated manufacturing industry, is a large consumer of water and therefore produce large quantities of colored wastewater. During industrial processing up to $10-60 \%$ of the used dyestuffs are released in the effluent, being a major source for polluting the water resources.

The majority of synthetic dyes - bioresistant organic polluants - are considered as recalcitrant xenobiotic compounds due to the presence of an $\mathrm{N}=\mathrm{N}$ bond and groups such as aromatic rings that are not easily degraded [1]. This wastewater that contains predominant dye substances is not only toxic to the biological world, its dark colour locks sunlight but leads to severe problems to the ecosystem. The discharge of these colored compounds into the effluents causes considerable environmental pollution by eutrophication of aquatic ecosystem and serious health-risks factors by bioaccumulation [2].

Therefore, decolorization of dyes is another important aspect of wastewater treatment before discharge into environment. There are several methods for dye removal: coagulation-flocculation, oxidationozonation, biological treatment, membrane technologies and adsorption techniques [3].

Adsorption is one of the most promising techniques applied for the decontamination of wastewater from dyes and it is considered superior compared to other available techniques for wastewater treatment in terms of initial cost, simplicity of design, and ease of operation [4]. Adsorption is a method that is preferred over other options because it is rapid, convenient and unaffected by the toxic contaminants [4].

\section{The Purpose of this Applicative Research}

This research proposed a method for decontamination/ decolorization of the industrial wastewater from ICPI microproduction leather dyeing and FROTTIEREX textile factory, using adsorbents macroporous ion exchange resin-IER. The removal of anions and cations from dye industry effluents can be carried out by ion exchange method, by passing the colored wastewater through the column of beds of IER [1].

\section{Materials and Methods}

In the research we used the following IER-PUROLITE type : strongly basic anion exchanger resins PUROLITE A 500, A500 Plus and PFA $500 \mathrm{MB}$, purchased from Purolite factory, Victoria, Brasov, Romania.

The studied industrial wastewaters contain Acid black 210, Direct black 234 [acid black NBH] [Sella Fast Black HM and HS-02- acid azo dyes], self-dispersible Pigment black 7 with modified surface from ICPI and contains Violet vinyl sulphone reactive dyes from FROTTIEREX. 
Citation: Deaconu M, Senin R, Stoica R, Athanasiu A, Crudu M, et al. (2016) Adsorption Decolorization Technique of Textile/Leather - Dye Containing Effluents. Int J Waste Resour 6: 212. doi:10.4172/2252-5211.1000212

Page 2 of 7

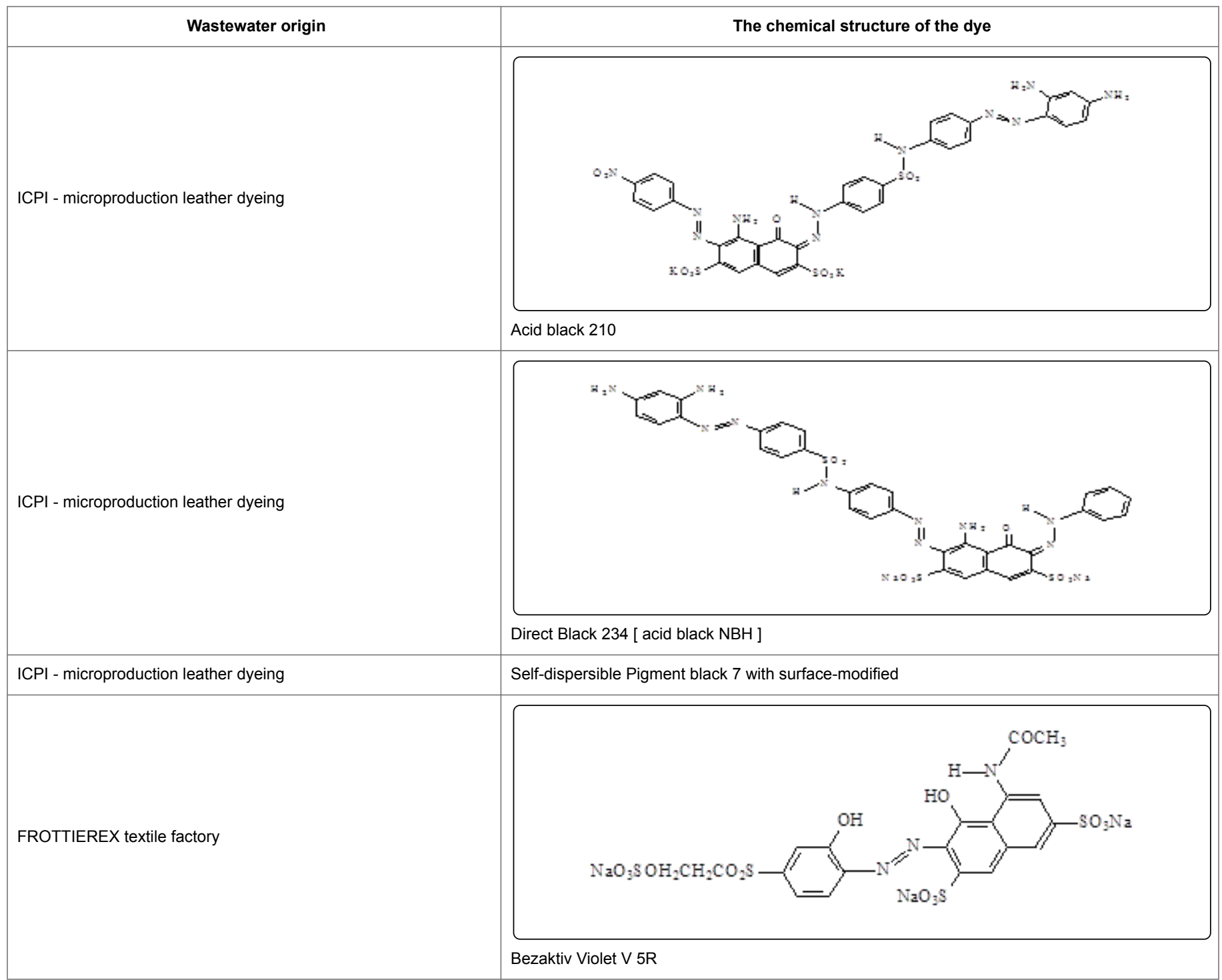

Table 1: Chemical structure of dyes - bioresistant organic polluants - contained in the wastewaters discolored with IER.

\section{Origin, Compozition and Quantity of Studied Wastewater}

The wastewater used in laboratory experiments in the treatment discoloration through macroporous ion exchange resins proceeds from (Table 2):

\begin{tabular}{|l|l|}
\hline \multicolumn{1}{|c|}{ Wastewater source } & \multicolumn{1}{c|}{ Working technique } \\
\hline $\begin{array}{l}\text { Leather and Footwear Research Institute- ICPI, branch of National R\&D Institute for } \\
\text { Textiles and Leather (INCDTP), Bucharest }\end{array}$ & Research leather - footwear and dyeing leather and furs \\
\hline FROTTIEREX textile factory, Bucharest & $\begin{array}{l}\text { Manufacturer of textile garments from dyed cotton for towels / bathrobes, bed } \\
\text { linen, tablecloths, upholstery fabrics }\end{array}$ \\
\hline
\end{tabular}

Table 2: Wastewater source. 
Citation: Deaconu M, Senin R, Stoica R, Athanasiu A, Crudu M, et al. (2016) Adsorption Decolorization Technique of Textile/Leather - Dye Containing Effluents. Int J Waste Resour 6: 212. doi:10.4172/2252-5211.1000212

Page 3 of 7

\begin{tabular}{|l|l|}
\hline Source & The quantity of wastewater $(\mathrm{ml})$ \\
\hline ICPI & 10000 \\
\hline FROTTIEREX textile factory & 20000 \\
\hline
\end{tabular}

Table 3: Quantity of treated wastewaters.

The studied industrial wastewaters contain besides the azo-dyes and other auxiliary chemicals necessary in the dyeing process (Table 4):

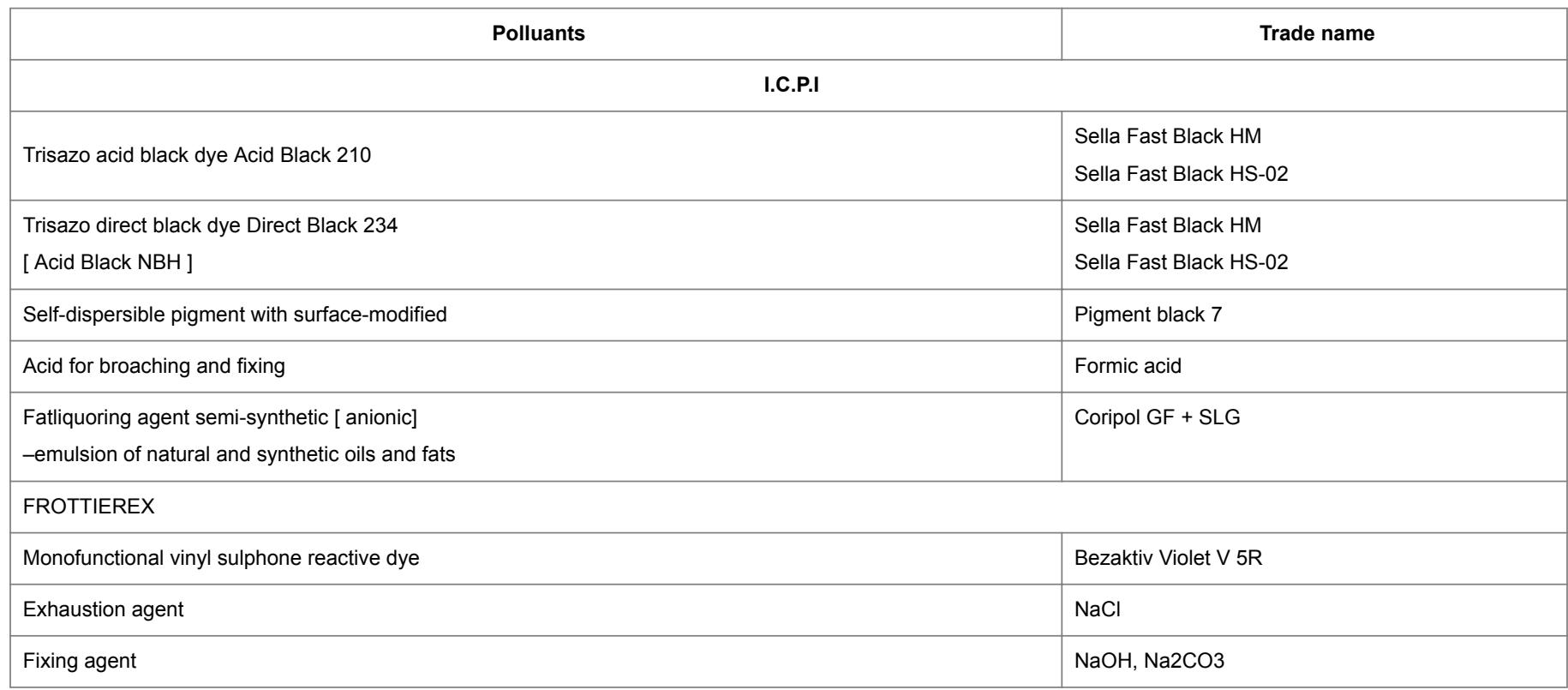

Table 4: Dyes and chemical pollutants existing in treated wastewater with IER.

\section{Adsorption}

The process of adsorption involves the ions, atoms or molecules of the adsorbate to transfer and adhere to the surface of the adsorbent creating a thin film. Adsorption technique can be divided into physical and chemical adsorption. Another term of the physical adsorption process is physisorption and it is controlled by physical forces such as Van der Waals forces, hydrophobicity, hydrogen bond, polarity, static interaction, dipole -dipole interaction, $\Pi-\Pi$ interaction etc. In the physical adsorption, pollutants get accumulated on adsorbent surface by the above mentions interactions while chemical adsorption is defined when the adsorbate is chemically bound to the adsorbent's surface due to the exchange of electrons [5].

The extent of adsorption depends on the nature of adsorbate such as molecular weight, molecular structure, molecular size, polarity and solution concentration. It also depends on the surface properties of adsorbent such as particle size, surface area, surface charge etc [5]. The efficiency of adsorption process depends on the physical and chemical properties of the adsorbents and adsorbate.

Adsorption capacity, surface area, availability and total cost, influence the adsorbent's selectivity. However due to the high cost associated with adsorbents production and regenerating, researchers are developing alternative cost effective and nonconventional potential adsorbents in the removal of dye from its aqueous solution [5].

In the laboratory as well as in industrial plants, ion exchange resins are used in columns. The water or solution to be treated flows through the resin. The fresh resin gets progressively loaded with the ions from the feed solution. Ions from the resin are released into the treated solution. At the end some of the ions from the feed escape into the pure solution, and operation is stopped [6-9].

For discoloration the industrial wastewaters were used the next types of polymeric ion exchange resins (Table 5):

\begin{tabular}{|c|c|c|c|c|}
\hline Name & Type & Ionic form & Total volum capacity & Remarks \& Applications \\
\hline PuroliteA 500 & $\begin{array}{l}\text { Strongly basic Type I, } \\
\text { macroporous polystyrenic }\end{array}$ & $\mathrm{Cl}-$ & $1.15 \mathrm{eq} / \mathrm{L}$ & $\begin{array}{l}\text { High capacity for extraction of minerals } \\
\text { dissolved and suspended matter. }\end{array}$ \\
\hline
\end{tabular}


Citation: Deaconu M, Senin R, Stoica R, Athanasiu A, Crudu M, et al. (2016) Adsorption Decolorization Technique of Textile/Leather - Dye

\begin{tabular}{|c|c|c|c|c|}
\hline & & & & $\begin{array}{l}\text { Optimum performance in deionization } \\
\text { and as an organic trap. }\end{array}$ \\
\hline PuroliteA 500Plus & $\begin{array}{l}\text { Strongly basic Type I, } \\
\text { macroporous polystyrenic }\end{array}$ & $\mathrm{Cl}-$ & $1.15 \mathrm{eq} / \mathrm{L}$ & $\begin{array}{l}\text { For removal of the more strong-held } \\
\text { colour bodies. Ensures good retention } \\
\text { of organic compounds and color levels. }\end{array}$ \\
\hline $\begin{array}{l}\text { Purolite [Purofine] } \\
\text { PFA } 500 \text { MB }\end{array}$ & $\begin{array}{l}\text { Strongly basic Type I, } \\
\text { macroporous polystyrenic }\end{array}$ & $\mathrm{Cl}-$ & $1.19 \mathrm{eq} / \mathrm{L}$ & $\begin{array}{l}\text { High efficiency and excellent kinetics. } \\
\text { High sorption capacity of complex } \\
\text { organic substances. Resisting to } \\
\text { osmotic and thermal shock. }\end{array}$ \\
\hline
\end{tabular}

Table 5: The types of IER studied.

The treatment columns were filled with different amounts of three types of resins, it passes through different amounts of wastewater, depending on the final result of discoloration, as illustrated in Table 6.

\begin{tabular}{|l|l|l|c|c|}
\hline \multirow{2}{*}{ Source } & $\begin{array}{l}\text { Column } \\
\text { of } \\
\text { IER }\end{array}$ & $\begin{array}{l}\text { Type of IER } \\
\text { used }\end{array}$ & $\begin{array}{l}\text { Amount of IER } \\
\text { from column, g }\end{array}$ & $\begin{array}{l}\text { Amount of } \\
\text { wastewater } \\
\text { passed } \\
\text { through } \\
\text { bed of IER, } \\
\text { mL }\end{array}$ \\
\hline \multirow{2}{*}{ ICPI } & 1 & Purolite A 500 & 400 & 2500 \\
\cline { 2 - 5 } & 2 & $\begin{array}{c}\text { Purolite PFA } \\
500 M B\end{array}$ & 150 & 800 \\
\hline \multirow{2}{*}{ FROTTIEREX } & 3 & Purolite A 500 & 400 & 1500 \\
\cline { 2 - 5 } & 4 & Purolite A 500 & 400 & 4000 \\
\hline & 5 & $\begin{array}{c}\text { Purolite A } \\
500 P l u s\end{array}$ & 400 & 4500 \\
\hline
\end{tabular}

Table 6: The amount of wastewater treated in different columns with IER.

Note: In column 3 was passed the neutralized wastewater.

The wastewaters were passed through the column containing beds of ion exchange resins and Figures 1 and 2 illustrate the decolored wastewaters taken in working.

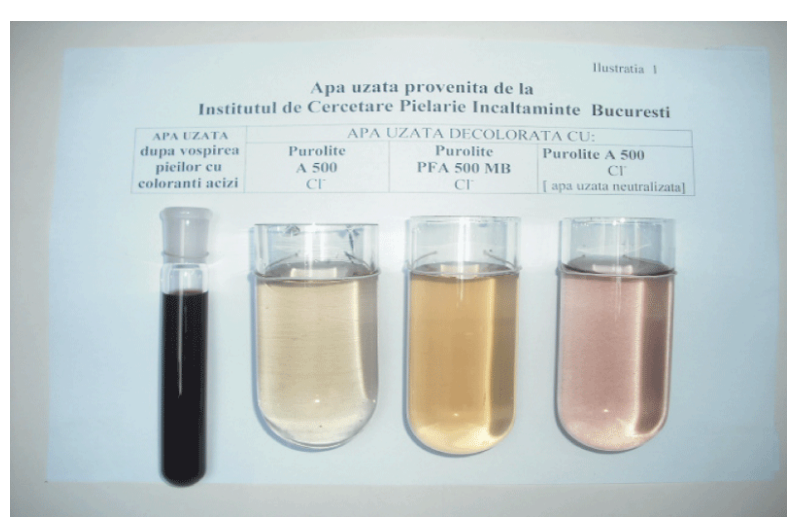

Figure 1: Discoloration of ICPI wastewater.

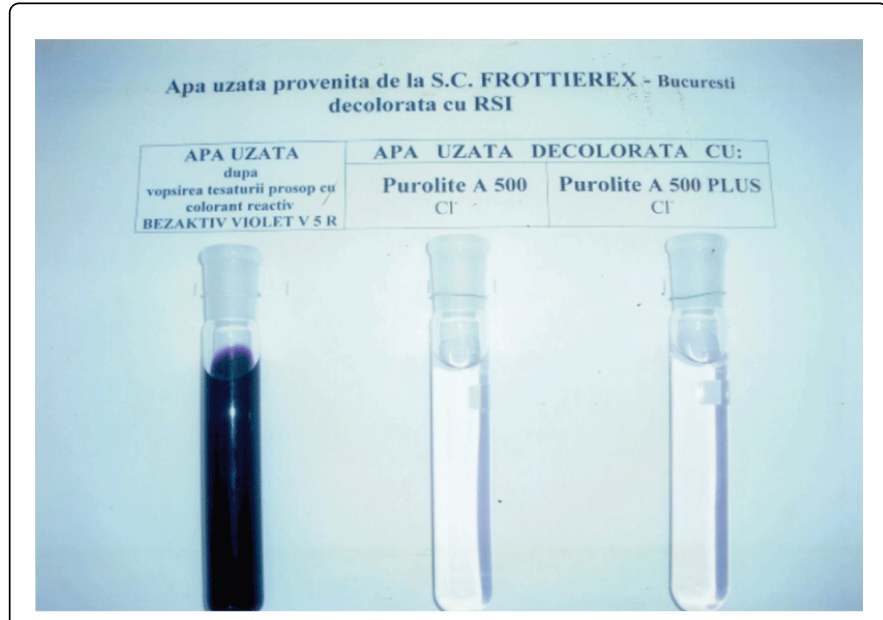

Figure 2: Discoloration of FROTTIEREX wastewater.

\section{Analytical methods for evaluating the decontamination/ discoloration process of wastewater with IER}

To determine the physical and chemical indicators of wastewater discolored following methods were used for analysis and instrumental analysis listed in Table 7.

\begin{tabular}{|l|l|l|l|}
\hline $\begin{array}{l}\text { No. } \\
\text { crt. }\end{array}$ & Analytical test & Standard & Analytical device \\
\hline 1 & $\mathrm{pH}$ & $\begin{array}{l}\text { SR EN } \\
\text { ISO10523/2012 }\end{array}$ & $\begin{array}{l}691 \quad \mathrm{pH} \text { Meter } \\
\text { Metrohm }\end{array}$ \\
\hline 2 & Conductivity & SR EN 27888/1997 & $\begin{array}{l}\text { Portable K912 } \\
\text { Conductivity meters, } \\
\text { Consort }\end{array}$ \\
\hline 3 & Total Solids & STAS 9187-84 & $\begin{array}{l}\text { Drying stove, electric } \\
\text { water bath }\end{array}$ \\
\hline 4 & Turbidity & $\begin{array}{l}\text { SR ISO } \\
7027-2001\end{array}$ & $\begin{array}{l}\text { Portable Turbidity } \\
\text { Meter HI 93703, } \\
\text { Hanna Instruments }\end{array}$ \\
\hline 5 & Chlorides & SR ISO 9297/2001 & Potentiometer titrator \\
\hline 6 & Sulphates & STAS 8601-70 & $\begin{array}{l}\text { Laboratory furnace, } \\
\text { sand bath }\end{array}$ \\
\hline
\end{tabular}


Page 5 of 7

\begin{tabular}{|l|l|l|l|}
\hline 7 & DOC-Cr & SR ISO 6060/1996 & $\begin{array}{l}\text { Boiling installation } \\
\text { with refluxing }\end{array}$ \\
\hline 8 & Total nitrogen & SR EN 12260-2008 & Analyser N/C 2100 S \\
\hline 9 & Spectrophotometry & - & $\begin{array}{l}\text { SPECORD UV-VIS } \\
\text { M42 Karl- Zeiss Jena }\end{array}$ \\
\hline
\end{tabular}

Table 7: Physical and chemical indicators monitored and analytical methods.

\section{Results and Discussion}

The research study presented above describes the experiments on the application of sequestrant macroporous polymer like ion exchange resins in order to discoloration/purify industrial wastewaters that containing dyestuffs.

The experimental study involved the purchase of wastewater [10000 or $20000 \mathrm{~mL}$ ] resulting from processes for dyeing cellulose materials and leathers from the technological platforms of ICPI and FROTTIEREX Factory in Bucharest.

Wastewater includes acid and direct trisazo dyes (Acid Black 210, Direct Black 234) and pigment with modified surface (Pigment Black 7) was not exhausted on the leather material, respectively vinyl sulphone reactive dye (Bezaktiv Violet V 5R) chemically unfixed on cellulose material, cotton.

We used three types of strongly basic anion exchange resins with macroporous structure: Purolite A 500, A 500 Plus and PFA 500 MB.

The colored studied wastewaters were passed through a laboratory plant that consists of column resin beds containing between 150-400 g IER.

The last stage of the research study was both to determine the parameters to characterize the quality of wastewater treated with the studied resins and the obtained discolored waters.

Experimental study also involves the identification and characterization of analytical methods to establish the various quality parameters of wastewater and discolored wastewater: $\mathrm{pH}$, solids-total, conductivity, chlorides, sulphates, total nitrogen, COD, turbidity and colour.

Analysis of the results of discoloration experiments of wastewater that containing dyes by using strongly basic anion ion exchange resins, as intermediate stage in the general flow of sewage highlights the following:

For wastewater containing acid and direct dyes and pigment with modified surface proceeds from ICPI.

Spectrophotocolorimetric as well as visual analysis shows those coloring matters in wastewaters that have not been exhausted on leather, are almost entirely retained by the resins used. Discoloration is not complete because, during the process of passage of wastewater through the bed of resin, the fatliquoring agent saturates the resin and hinders the adsorption of coloring materials. The UV - Visible absorption spectra indicate a decoloration of $\sim 96 \%$ (Figure 3).

At the same time it was shown that the resins used are helpful for wastewater treatment, this fact was demonstrated by reducing chemically of indicator DOC-Cr with $\sim 80-90 \%$, reduction of a sulphate indicator with $\sim 95 \%$, the turbidity parameter showing a reduction with $\sim 80-90 \%$ of suspensions which decrease the water transparency (Tables 8 and 9), depending on the type of resin used.

For an industrial waste water containing vinylsulphonic reactive dye chemically unfixed and hydrolyzed, which was removed at the washing process of dyed cellulose material, from FROTTIEREX factory.

Spectrophotocolorimetric as well as the visual analysis show an incomplete discoloration of $\sim 92 \%$, because of the dye structure and its low molecular weight (Figure 4).

Physico - chemical parameters of treated water are relatively improved, thus the turbidity is reduced by $\sim 85 \%$, DOC-Cr with $50-60 \%$ and total nitrogen by $~ 50-60 \%$ depending on the type of resin used and the residual dye (Tables 8 and 10).

The UV-visible spectrum of the colored and the decolored waters is illustrated by Figures 3 and 4 .

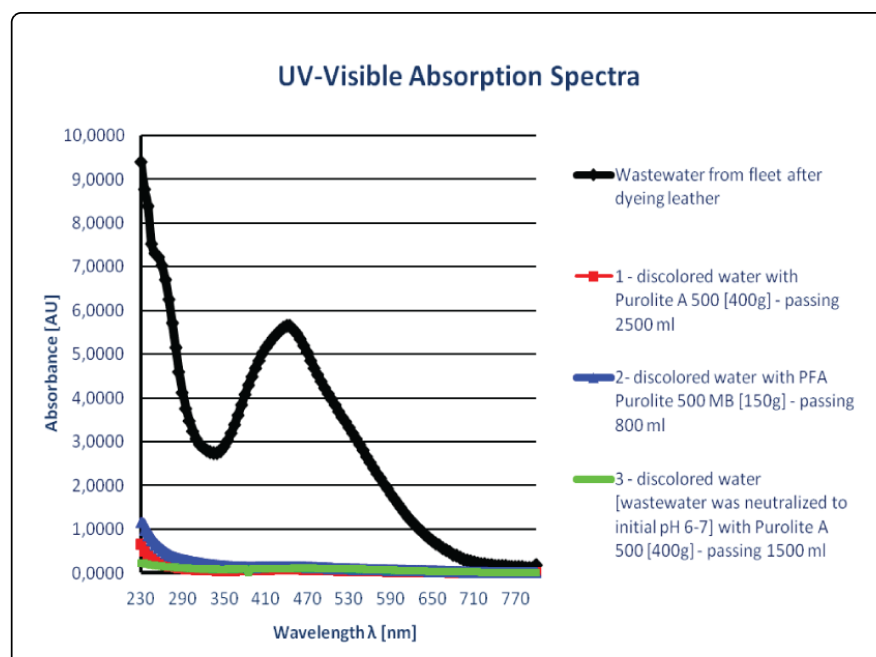

Figure 3: UV-visible spectrophotometric analysis of the colored and the decolored waters of ICPI.

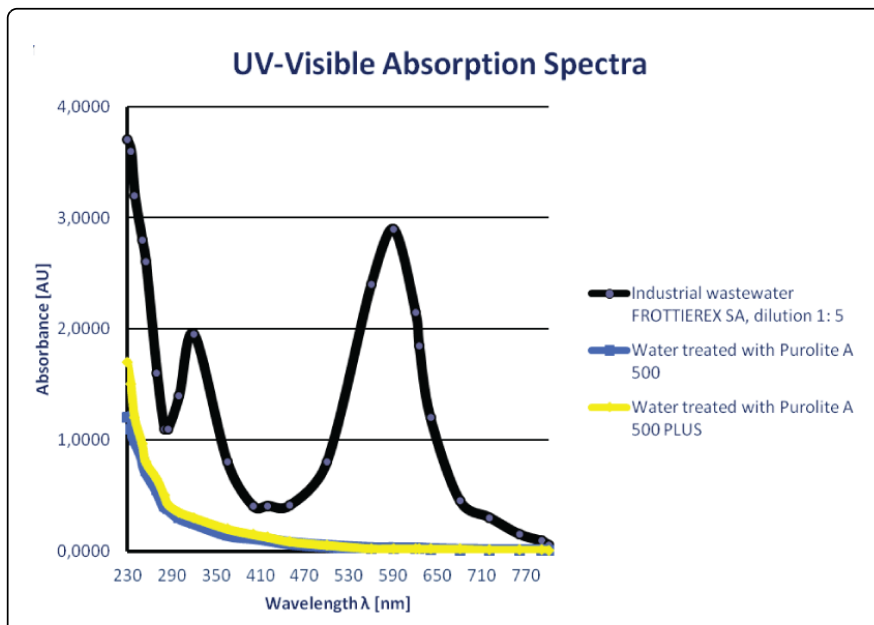

Figure 4: UV-visible spectrophotometric analysis of the colored and the decolored waters of FROTTIEREX.

The parameters of physico-chemical indicators are presented in Table 8. 


\begin{tabular}{|c|c|c|c|c|c|c|c|c|c|}
\hline $\begin{array}{l}\text { Physico- } \\
\text { chemical } \\
\text { indicators }\end{array}$ & $\begin{array}{l}\text { Waste water } \\
\text { ICPI } \\
\begin{array}{l}\text { Black acid } \\
\text { dyes }\end{array}\end{array}$ & $\begin{array}{l}\text { Purolite } \\
\text { A } 500\end{array}$ & $\begin{array}{l}\text { Purolite } \\
\text { PFA } 500 \text { MB }\end{array}$ & $\begin{array}{l}\text { Purolite A } 500 \\
-\quad \text { neutralized } \\
\text { waste water }\end{array}$ & $\begin{array}{l}\text { Waste water } \\
\text { FROTTIEREX } \\
\text { Violet reactive dye }\end{array}$ & Purolite A 500 & $\begin{array}{l}\text { Purolite } \\
\text { PLUS }\end{array}$ & A & 500 \\
\hline $\mathrm{pH}$ & 3.11 & 2.7 & 2.4 & 5.5 & 11.40 & 11.20 & 11.30 & & \\
\hline Solids total, mg/L & 3118 & 2711 & 2344 & 5128 & 81070 & 64200 & 63600 & & \\
\hline Sulphates, mg/L & 1.553 & 109 & 5.1 & 88.4 & 1768 & 1708 & 1746 & & \\
\hline $\begin{array}{l}\text { Total nitrogen, } \\
\mathrm{mg} / \mathrm{L}\end{array}$ & 38.4 & 23.9 & 19.4 & 20.6 & 14.10 & 5.10 & 6.90 & & \\
\hline $\mathrm{DOC}-\mathrm{Cr}, \mathrm{mgO} / \mathrm{L}$ & 1643 & 338 & 214 & 111 & 2023 & 988 & 706 & & \\
\hline Turbidity, FTU & 95.6 & 8.67 & 10.7 & 16.8 & 149 & 28 & 18 & & \\
\hline Colour, note & $\begin{array}{l}5 \\
\text { Dark brown }\end{array}$ & $\begin{array}{l}1-2 \\
\text { Light } \\
\text { brown }\end{array}$ & $\begin{array}{l}1-2 \\
\text { Lightyellowish } \\
\text { brown }\end{array}$ & $\begin{array}{l}2 \\
\text { Light reddish } \\
\text { brown }\end{array}$ & $\begin{array}{l}5 \\
\text { Dark violet }\end{array}$ & 2 & 2 & & \\
\hline
\end{tabular}

Table 8: Physico-chemical indicators of colored wastewater and of decolored water.

\section{The efficiency of decontamination/discoloration process}

Based on the obtained results from physico-chemical analysis for determining the indicators characteristics of wastewater and treated water, to demonstrate the efficiency of treatment method using ion exchange resins, the discoloration process efficiency was calculated (Tables 9 and 10).

\begin{tabular}{|l|l|l|l|}
\hline $\begin{array}{l}\text { Physico } \\
\text { chemical } \\
\text { indicators }\end{array}$ & A 500 & PFA 500 MB & $\begin{array}{l}\text { A 500 neutralized } \\
\text { wastewater }\end{array}$ \\
\hline Solids total & 13 & 25 & - \\
\hline Sulphates & 93 & 97 & 94 \\
\hline Total nitrogen & 38 & 49 & 48 \\
\hline DOC-Cr & 80 & 87 & 93 \\
\hline Turbidity & 91 & 89 & 82 \\
\hline Colour & 96 & 96 & 96 \\
\hline
\end{tabular}

Table 9: The efficiency of decontamination/ discoloration process, wastewater from IPCI.

\begin{tabular}{|l|l|l|}
\hline $\begin{array}{l}\text { Physico-chemical } \\
\text { indicators }\end{array}$ & A500 & A500 Plus \\
\hline Solids total & 21 & 22 \\
\hline Total nitrogen & 64 & 51 \\
\hline DOC-Cr & 51 & 65 \\
\hline Turbidity & 81 & 88 \\
\hline Colour & 92 & 92 \\
\hline
\end{tabular}

Table 10: The efficiency of decontamination/discoloration process, wastewater from Frottierex.

\section{Conclusions}

The main objective of wastewater treatment is the removal therefrom of, the substances found in suspension, colloidal substances or those dissolved into solution, toxic substances, microorganism, the ultimate goal representing environmental protection [emissaries, soil and air] in general and a health of humans and living beings particularly.

The problem of wastewater treatment has now become more complex due to residual substances existing in waste water which, very little removed or practical unmodified through the steps of conventional mechanical-biological treatment (detergents, phosphates, nitrogen based compounds, dyestuffs, salts inorganic, persistent organic compounds, pesticides, other various chemicals) create extremely serious problems for the environmental and living matters.

This study shows that the strongly basic anion exchanger with macroporous structure containing tertiary amine functionalized on the polystyrene cross linked with divinylbenzene matrix can be practically used for color removal from the wastewaters containing the bio resistant organic pollutants for environment: anionic azo acid dyes, reactive dyes and self-dispersible pigments.

The decolorization performance of IER was evaluated by the yield of quality parameters of treated wastewater: remove of $95 \%$ for sulphates, $38-64 \%$ for total nitrogen, $50-85 \%$ for DOC-Cr, $80-90 \%$ for turbidity and $\sim 95 \%$ for colour, depending on the type of wastewater: leather or textile dyeing.

The research conducted within the Romanian Nucleu Project "The utilization of macroporous resin by developing active and passive nanostructures for wastewater treatment" demonstrated that the unconventional discoloration-treatment process for industrial wastewater containing dyestuffs is a viable intermediate step, usefulness and effectiveness of their retention from wastewater.

The dyes adsorption technology - bioresisting pollutants - through polymeric ion exchange resins from wastewater represent an important step in the advanced treatment technology of wastewater system, thus treated waters finally can be discharged into sewers or receiving waters 
Citation: Deaconu M, Senin R, Stoica R, Athanasiu A, Crudu M, et al. (2016) Adsorption Decolorization Technique of Textile/Leather - Dye

in accordance to the Standards on pollutant loading limits of industrial wastewater and wastewater discharge conditions in sewers networks or directly into sewage treatment plants.

\section{Acknowledgements}

This work was financially supported by MECS-UEFISCDI, in the frame of Romanian PN II-Partnership - Joint Applied Research Projects Program - Contract No. 216/2014, phase II/2015 and the Nucleu Project PN 09.09.04.14. phase 01-06/ 2014-2015.

\section{References}

1. Raghavan V, Basha SJS, Jegan J (2013) Review on efficacious methods to decolorize reactive azo dye. Journal of Urban and Environmental Engineering 7: 30-47.

2. Naidja L (2010) Elimination du colorant orange II en solution aqueuse, par voie photochimique et par adsorption.
3. Greluk M, Hubiki Z, Wolowicz A (2011) Sorption of the acid dyes onto strongly basic anion exchanger: Kinetic and equilibrium studies. Challenges of modern Technology 2: 74-78.

4. Kyzas G, Matis KA (2015) Nanoadsorbents for polluants removal: A review. Journal Of Molecular Liquids 203: 159-168.

5. Dawood S, Sen TK (2014) Review on Dye Removal from Its Aqueous into Alternative Cost Effective and Non-Conventional Adsorbents. Journal of Chemical and Process Engineering 1: 1-7.

6. Purolite: Product information, Product Summary Guide.

7. Huber P, Carre B (2012) Decolorization of process waters in deinking mills and similar applications: a review. BioResources 7: 1366-1382.

8. Oubagha N (2011) Decontamination des eaux contenant les colorants textiles et les adjuvants par des materiaux naturels et synthetique. Universite Mouloud Mammeri Tizi Ouzou. Republique Algerienne.

9. Purolite- Product Data Sheet (2014). 